\title{
Effect of chamomile extract on the welfare of laying Japanese quail
}

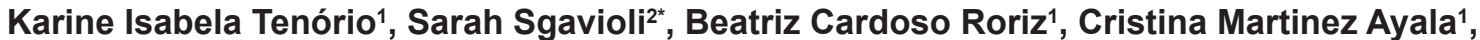 Wellington dos Santos ${ }^{1}$, Paulo Henrique Mazza Rodrigues ${ }^{3}$, Vitor Rosa de Almeida ${ }^{4}$, Rodrigo Garófallo Garcia ${ }^{1}$}

\footnotetext{
${ }^{1}$ Universidade Federal da Grande Dourados, Faculdade de Ciências Agrárias, Dourados, MS, Brazil.

2 Universidade Brasil, Descalvado, SP, Brazil.

${ }^{3}$ Universidade de São Paulo, Faculdade de Medicina Veterinária e Zootecnia, Departamento de Nutrição e Produção Animal, Pirassununga, SP, Brazil.

${ }^{4}$ Universidade Estadual Paulista "Júlio de Mesquita Filho", Programa de Pós-graduação em Zootecnia, Jaboticabal, SP, Brazil.
}

\begin{abstract}
The objective of this study was to evaluate the effect of chamomile extract on Japanese quail on their performance, animal behavior, tonic immobility, body injuries, and surface temperature. The trial was conducted using 108 quail distributed in a completely randomized experimental design, with three treatments $(0,2.5$, and $5.0 \mathrm{~g}$ chamomile/ $\mathrm{kg}$ of feed), six replicates, and six birds per treatment, evaluated in six measures repeated in time $(14,28,42,56,70$, and 84 days of trial). The inclusion of chamomile presented a quadratic effect on sitting behavior, estimating the inclusion of $1.8 \mathrm{~g}$ chamomile $/ \mathrm{kg}$ to maximize this behavior. There was a decreasing linear effect for aggressive pecking, that is, the higher the inclusion of chamomile in the diet, the lower the expression of this behavior. The inclusion of 1.8-5.0 g chamomile/ $\mathrm{kg}$ in a Japanese quail diet reduces the behavior of aggressive pecking, in addition to keeping the birds seated longer. These results are innovative because they show in the literature for the first time that chamomile supplemented in Japanese quail diets has the capacity to modulate the behavior of the quail, leading to an improvement in the welfare of quail raised in cages.
\end{abstract}

Key Words: Coturnix cotunix japonica, infrared thermography, Matricaria recutita, phytotherapics, tonic immobility

\section{Introduction}

Because of the financial returns and rapid growth in demand for quail products such as fresh eggs, quail production has become more important in the poultry sector (Silva et al., 2012). Therefore, production systems have been intensified by increasing the number of birds in conventional cages. This has had a negative impact on the welfare of the quail due to constant competition for space and food (Pavan et al., 2005). Although this breeding system contributes to an increase of stressrelated aggression, quail naturally exhibit aggressiveness and this may also be observed in small groups raised in semi-intensive systems. This aggressiveness can result in injuries, high mortality, and a decrease in productivity (Schmid and Wechsler, 1997).

Received: May 12, 2017

Accepted: August 1, 2017

*Corresponding author: sarahsgavioli@yahoo.com.br

http://dx.doi.org/10.1590/S1806-92902017000900008

How to cite: Tenório, K. I.; Sgavioli, S.; Roriz, B. C.; Ayala, C. M.; Santos, W.; Rodrigues, P. H. M.; Almeida, V. R. and Garcia, R. G. 2017. Effect of chamomile extract on the welfare of laying Japanese quail. Revista Brasileira de Zootecnia 46(9):760-765

Copyright (c) 2017 Sociedade Brasileira de Zootecnia. This is an Open Access article distributed under the terms of the Creative Commons Attribution License (http://creativecommons.org/licenses/by/4.0/), which permits unrestricted use, distribution, and reproduction in any medium, provided the original work is properly cited.
Studies have shown that some plants, such as chamomile, green tea, and lemon grass, have calming and stressreducing properties in humans (Rocha et al., 2008). These effects have also been proven in bird research (Sarker et al., 2010; Lourenço et al., 2013, Royer et al., 2015).

Chamomile (Matricaria chamomilla L.) is classified under plant family composites. It contains flavones apigenin and essential volatile oil such as bisabol oxide B, -bisabolo, chamazulene, and bisaboloxide A (McKay and Blumberg, 2009). It has been traditionally used for medicinal purposes and has antioxidant and antimicrobial activities. Animal model studies indicate potent anti-inflammatory action, some anti mutagenic and cholesterol-lowering activities, as well as antispasmodic and anxiolytic effects (McKay and Blumberg, 2009).

Some research, especially on chamomile, has been already done on their effect to minimize stress in quail (Marques et al., 2010, Galib and Khalel, 2011; Mahmmod, 2013). However, there are little data on the behavior of quail fed chamomile during the laying period, since in general, evaluations have been made on performance and blood or microbiological parameters.

The objective of the study was to evaluate the inclusion of chamomile extract on the performance, animal behavior, tonic immobility, body injuries, and surface temperature of laying quail and the use of high concentrations of 
chamomile allowed us to evaluate whether the calming properties of chamomile, already confirmed in humans (Rocha et al., 2008), are efficient to modulate the expression of stress-related behaviors in these birds.

\section{Material and Methods}

The experimental protocol was approved by the Committee on Ethics in the Use of Animals - CEUA (case no. 031/2014) and conducted in Dourados, MS, Brazil (latitude $22^{\circ} 13^{\prime} 16^{\prime \prime}$ South and longitude $54^{\circ} 48^{\prime} 20^{\prime \prime}$ West). The experimental period was carried out between February 21 and May 16, 2015.

A total of 108 180-day-old Japanese quail (Coturnix coturnix japonica) were housed in a conventional shed in cages with four subdivisions measuring $32 \times 33 \times 17 \mathrm{~cm}$ each. Each unit was equipped with nipple drinkers and metal feeders. Water and feed were provided at will throughout the experimental period. A 17-h-per-day light program was used ( $12 \mathrm{~h}$ of natural light $+5 \mathrm{~h}$ of artificial light).

The experimental diets were based on corn and soybean meal and formulated according to the requirements for laying quail established by Rostagno et al. (2011) (19.94\% crude protein, 2,800 kcal $/ \mathrm{kg}$ metabolizable energy, 3.10\% $\mathrm{Ca}, 0.32 \%$ available $\mathrm{P}, 0.9 \%$ digestible methionine + cysteine, $1.08 \%$ digestible lysine, and $0.68 \%$ digestible threonine), with a $0.5 \%$ variable, whereby the chamomile extract (Matricaria recutita) was added, and/or inert, according to the treatment.

The extract was obtained from the chamomile flower. The flowers were harvested, dried in the shade, and subjected to the gamma sterilization process. The flowers were then ground and after grinding, formed a fine, hygroscopic powder of yellowish color, with a pleasant aromatic odor.

The temperature and relative humidity were measured with two digital thermo-hygrometers (Instrutemp, ITHT 2250, São Paulo, Brazil) located at the height of the birds at equidistant points. The average of the maximum, absolute maximum, average of the minimum, and absolute minimum temperatures were measured, with values of 31.2, 33.6, 21.4 , and $18.7^{\circ} \mathrm{C}$, respectively. For the relative humidity, the mean of the maximum, absolute maximum, average of the minimum, and absolute minimum were measured, with values of $80.5,86.5,56.5$, and $44.8 \%$, respectively.

The behavior of the quail was analyzed by indirect monitoring (Becker and Dalponte, 1999) through videos made with digital cameras. At the end of each trial period, at 09:00 h, six videos of $15 \mathrm{~min} /$ treatment were recorded, totaling 108 videos. In each video, 30 different recordings were made, spaced every half minute.
The images were analyzed for the frequency of the following behaviors, adapted from Nazareno et al. (2011) and expressed as a percentage: sitting - body of the bird in contact with the cage floor; feeding - consuming or pecking food; drinking - consuming water; preening - exploring feathers with the beak for both maintenance and investigation; non-aggressive pecking (NAP) - lightly pecking other birds non-aggressively; aggressive pecking (AP) - strongly pecking other birds, thereby provoking aggressive reaction; comfort - stretching the wings and legs on the same side of the body simultaneously, shaking and ruffling feathers, and flapping wings; standing still - bird standing with no movement; and standing and moving - the bird standing with constant movement, which did not fit the previous behaviors.

The eggs in each plot were counted every morning to calculate relative egg production. At the end of each cycle, the leftover ration was weighed to obtain the feed intake and calculate the feed conversion $\mathrm{kg} / \mathrm{dz}$. The performance data evaluated were: daily feed intake, feed conversion per dozen eggs, and relative egg production.

Body surface temperature (BST) was recorded at the end of each cycle by thermographic camera (Testo ${ }^{\circledR}$, Lenzkirch, Germany), with a precision of $\pm 0.1{ }^{\circ} \mathrm{C}$ and in the spectrum $7.5-13 \mu \mathrm{m}$. Four regions of the body (wing, head, leg, and back) were used to determine BST by means of equation 1, according to Richards (1971):

$\operatorname{BST}=\left(0.12 \mathrm{~T}_{\text {wing }}+\left(0.003 \mathrm{~T}_{\text {head }}\right)+\left(0.15 \mathrm{~T}_{\text {leg }}\right)+\left(0.70 \mathrm{~T}_{\text {back }}\right)\right.$

The BST of the different regions of the quail were obtained from thermographic images using IRSoft 3.1 software (Testo ${ }^{\circledR}$, Lenzkirch, Germany), delineating the specific body areas of the birds. The emissivity adopted from the bird surface was 0.98 , as proposed by Nääs et al. (2010).

To evaluate tonic immobility, one quail at a time was quickly flipped over and placed in a dorsal position on a flat surface, with pressure exerted on the breast for $3 \mathrm{~s}$, then the time was measured. To be considered in a state of tonic immobility, the bird must remain immobile for at least $10 \mathrm{~s}$ (Heiblum et al., 1998).

Body injuries were evaluated according to the presence or absence of lesions on the back, tail, wings, and head of the birds at the end of each laying cycle.

The birds were distributed in a completely randomized design composed of three treatments $(0,2.5$, and $5.0 \mathrm{~g}$ of chamomile $/ \mathrm{kg}$ of feed), in six replications, with six birds each, and evaluated in six-time measurements $(14,28,42$, 56,70 , and 84 experimental days).

The data were analyzed using SAS software (Statistical Analysis System, version 9.0). Before the actual analysis, the data were analyzed for the presence of disparate 
information ("outliers") and normality of residuals (ShapiroWilk). Variance analyses were done according to the PROC MIXED procedure, by having the days of experiment as measures repeated in time. The model included the fixed effects of treatments (chamomile levels), days (14, 28, 42, $56,70$, and 84$)$, and the treatment $\times$ day interaction, by means of experimental model (Equation 2):

$\mathrm{Y}_{\mathrm{ijk} \mathrm{l}}=\mu+(\text { treatments })_{\mathrm{i}}+\mathrm{e}_{\mathrm{ij}}+(\text { days })_{\mathrm{k}}+(\text { treatments } \times \text { days })_{\mathrm{ik}}+\mathrm{e}_{\mathrm{ikl}}$,

in which $\mathrm{Y}$ is the dependent variables, $\mu$ is the overall mean, $\mathrm{e}_{\mathrm{ij \textrm {k }}}$ is the error term associated with experimental unit (replication), and $\mathrm{e}_{\mathrm{ikl}}$ is the error term associated with subexperimental unit (time). Among 15 different covariance structures tested, the model used was chosen based on the lower value of Corrected Akaike Information Criterion (AICC) (Wang and Goonewardene, 2004). The treatment effect was decomposed into linear effect and linearity deviation (quadratic effect) and the day effect was compared using the Tukey test. The nonparametric statistical analyses of the body injuries of the birds were done by comparing means by Fischer's exact test. A significance level of 5\% was used for all the tests.

\section{Results}

The objective of the study was to evaluate the inclusion of chamomile extract on the performance, animal behavior, tonic immobility, body injuries, and surface temperature of laying quail. The inclusion of chamomile presented a quadratic effect $(\mathrm{P}=0.0073)$ on sitting behavior $(-60.56$ chamomile $^{2}+21.5$ chamomile $\left.+13.06 ; \mathrm{R}^{2}=0.97\right)$, estimating the inclusion of $1.8 \mathrm{~g}$ of chamomile $/ \mathrm{kg}$ of feed for maximization of sitting. There was a decreasing linear effect $(\mathrm{P}=0.0261)$ for AP $(-1.56$ chamomile +0.95 ; $\left.\mathrm{R}^{2}=0.61\right)$, that is, the higher the inclusion of chamomile in the diet, the lower the expression of this behavior (Table 1).

Feeding behavior was influenced by days $(\mathrm{P}=0.0007)$, with greater expression on the 42nd, 70th, and 84th experimental days (Table 1). Non-aggressive pecking and AP behaviors were influenced by days $(\mathrm{P}=0.0236$ and $\mathrm{P}=0.0238$, respectively). The highest intensity of NAP behavior was observed on day 14 , but did not differ statistically from days 42, 56, 70, and 84. Aggressive pecking was highest on day 14 , but not statistically different from day 56 of the experiment (Table 2). Similar results were observed for the BST, which had an effect $(\mathrm{P}<0.0001)$ in relation to days (Table 2), with a higher temperature on day 14 , as compared with the other days.

The days affected the performance of the birds, since the feed intake was higher and feed conversion worse on the 84th day $(\mathrm{P}<0.0001)$. Relative production was higher on the 28th, 56th, and 84 th days $(\mathrm{P}<0.0001)$, but did not differ statistically from the relative production on the 70th day (Table 2). The inclusion of chamomile did not influence the performance of the birds (relative production, $\mathrm{P}=0.1160$; feed intake, $\mathrm{P}=0.4760$; and feed conversion, $\mathrm{P}=0.7092$ ).

Table 1 - Behaviors expressed by Japanese quail subjected to different levels of chamomile in the diet

\begin{tabular}{|c|c|c|c|c|c|c|c|c|c|}
\hline Treatment & Sitting & Feeding & Drinking & Preening & $\begin{array}{c}\text { Non-aggressive } \\
\text { pecking }\end{array}$ & $\begin{array}{l}\text { Aggressive } \\
\text { pecking }\end{array}$ & $\begin{array}{l}\text { Comforting } \\
\text { moves }\end{array}$ & $\begin{array}{l}\text { Standing } \\
\text { still }\end{array}$ & $\begin{array}{c}\text { Standing with } \\
\text { movement }\end{array}$ \\
\hline \multicolumn{10}{|c|}{ Chamomile level (g/kg) } \\
\hline 0 & 13.06 & 17.60 & 4.75 & 3.29 & 2.94 & 1.13 & 0.85 & 13.42 & 42.94 \\
\hline 2.5 & 14.65 & 18.49 & 4.12 & 3.67 & 2.20 & 0.20 & 0.88 & 13.60 & 41.98 \\
\hline 5.0 & 8.67 & 22.00 & 4.38 & 2.22 & 2.42 & 0.35 & 0.62 & 13.87 & 45.47 \\
\hline \multicolumn{10}{|l|}{ Experimental day } \\
\hline 14 & 13.34 & $17.38 \mathrm{bc}$ & 4.05 & 2.04 & $3.20 \mathrm{a}$ & $1.34 \mathrm{a}$ & 0.89 & 12.85 & 44.93 \\
\hline 28 & 14.13 & $15.88 \mathrm{c}$ & 4.19 & 2.90 & $2.02 \mathrm{~b}$ & $0.31 \mathrm{~b}$ & 0.59 & 14.68 & 45.31 \\
\hline 42 & 10.20 & $23.30 \mathrm{a}$ & 5.30 & 3.34 & $2.44 \mathrm{ab}$ & $0.18 \mathrm{~b}$ & 0.77 & 12.20 & 42.28 \\
\hline 56 & 13.04 & $17.19 b c$ & 3.54 & 3.56 & $2.31 \mathrm{ab}$ & $0.77 \mathrm{ab}$ & 1.12 & 15.04 & 43.43 \\
\hline 70 & 11.85 & $21.03 \mathrm{abc}$ & 4.32 & 3.15 & $2.40 \mathrm{ab}$ & $0.49 b$ & 0.72 & 13.75 & 42.28 \\
\hline 84 & 10.20 & $21.39 \mathrm{ab}$ & 5.08 & 3.38 & $2.76 \mathrm{ab}$ & $0.31 b$ & 0.63 & 13.27 & 42.54 \\
\hline \multicolumn{10}{|l|}{ Probability } \\
\hline Chamomile (C) & $0.0181 *$ & $0.4636 \mathrm{NS}$ & $0.8015 \mathrm{NS}$ & $0.2026 \mathrm{NS}$ & $0.5997 \mathrm{NS}$ & $0.0221 *$ & $0.6301 \mathrm{NS}$ & $0.9661 \mathrm{NS}$ & $0.6343 \mathrm{NS}$ \\
\hline Days (D) & $0.1880 \mathrm{NS}$ & $0.0007 *$ & $0.0619 \mathrm{NS}$ & $0.1969 \mathrm{NS}$ & $0.0236^{*}$ & $0.0238^{*}$ & $0.3403 \mathrm{NS}$ & $0.2010 \mathrm{NS}$ & $0.5803 \mathrm{NS}$ \\
\hline $\mathrm{C} \times \mathrm{D}$ & $0.3613 \mathrm{NS}$ & $0.7042 \mathrm{NS}$ & $0.0939 \mathrm{NS}$ & $0.7182 \mathrm{NS}$ & $0.0722 \mathrm{NS}$ & $0.1547 \mathrm{NS}$ & $0.1488 \mathrm{NS}$ & $0.5100 \mathrm{NS}$ & $0.7258 \mathrm{NS}$ \\
\hline $\mathrm{L}$ effect ${ }^{1}$ & $0.0069 *$ & $0.2491 \mathrm{NS}$ & $0.7037 \mathrm{NS}$ & $0.1975 \mathrm{NS}$ & $0.4938 \mathrm{NS}$ & $0.0261 *$ & $0.4518 \mathrm{NS}$ & $0.7983 \mathrm{NS}$ & $0.5086 \mathrm{NS}$ \\
\hline$Q$ effect $^{2}$ & $0.0073^{*}$ & $0.6849 \mathrm{NS}$ & $0.5945 \mathrm{NS}$ & $0.2050 \mathrm{NS}$ & $0.4642 \mathrm{NS}$ & $0.0641 \mathrm{NS}$ & $0.5615 \mathrm{NS}$ & $0.9764 \mathrm{NS}$ & $0.5008 \mathrm{NS}$ \\
\hline SEM & 0.64 & 0.80 & 0.23 & 0.21 & 0.15 & 0.11 & 0.08 & 0.44 & 0.81 \\
\hline
\end{tabular}

NS - Not significant; SEM - standard error of the mean.

* Significant at $5 \%$ probability.

Averages compared by Tukey test/regressions.

${ }^{1}$ Linear effect: aggressive pecking: -1.56 chamomile $+0.95 ; \mathrm{R}^{2}=0.61$.

${ }^{2}$ Quadratic effect: sitting: -60.56 chamomile ${ }^{2}+21.5$ chamomile $+13.06 ; \mathrm{R}^{2}=0.97$. 
Chamomile treatment and days had no effect $(\mathrm{P}=0.8119$ and $\mathrm{P}=0.0879$, respectively) on tonic immobility time (Table 2). Wounds on the head, back, and wing (Table 3) had an effect $(\mathrm{P}=0.0001, \mathrm{P}=0.0157$, and $\mathrm{P}=0.0276$, respectively $)$ on the experimental days, with a lower incidence of injuries occurring at 14 days.

\section{Discussion}

The behavior of a bird can be used as a direct measure of its welfare (Nazareno et al., 2011). The chamomile inclusion in the quail diet allowed the birds to remain seated for more time, without affecting the performance of the birds, besides reducing the aggressive pecking behavior. These results indicate that chamomile inclusion in quail diets during the laying period has a positive effect on bird welfare due to the modulation of stress-related behaviors (Nääs et al., 2010). The anxiolytic properties of chamomile that provide sedative and calming effects (Yuan et al., 2004) may have contributed to these results.

The chamomile is one of the most widely used medicinal plants in the world. Chamomile is preferred for its pleasant taste and calming, sedative effects, as well as its long established medicinal properties (Srivastava et al., 2010).

Marques et al. (2010) described only a tendency to aggressive pecking reduction in quail fed chamomile with

Table 2 - Performance, body surface temperature, and tonic immobility time of Japanese quail subjected to different levels of chamomile in the diet

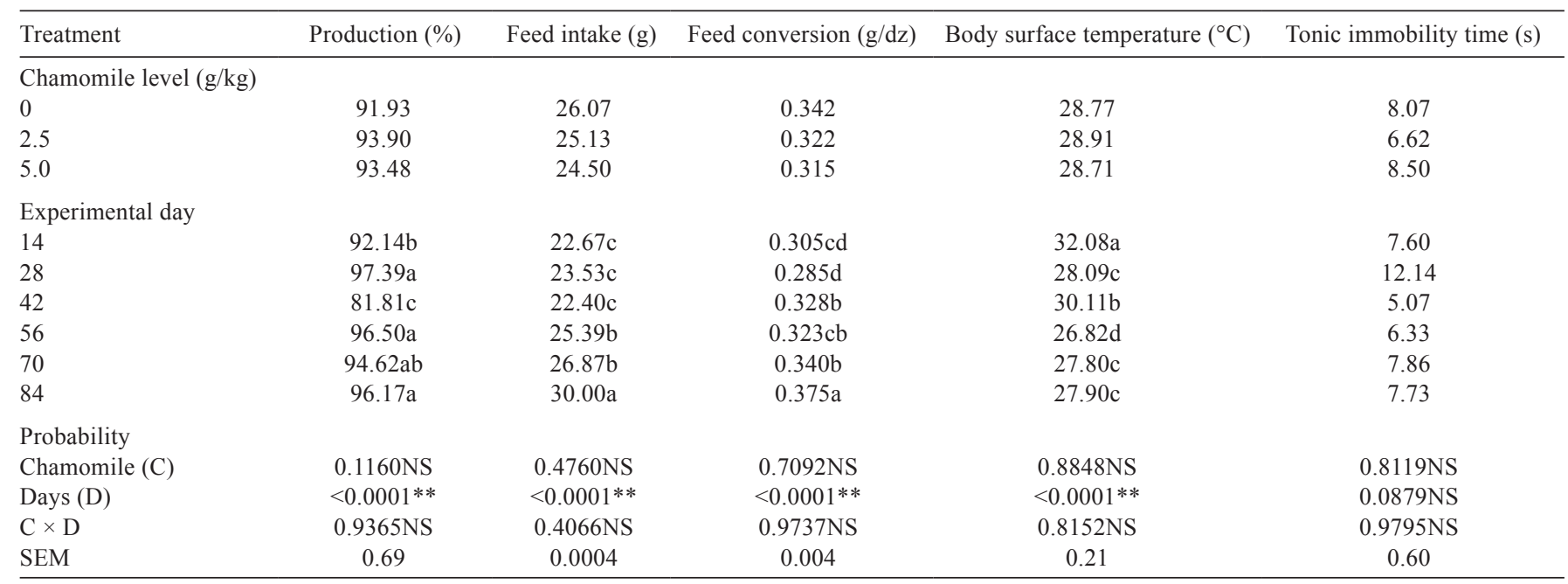

NS - not significant; SEM - standard error of the mean.

** Significant at $1 \%$ probability.

Averages compared by Tukey test.

Table 3 - Body injuries assessed in Japanese quail subjected to different levels of chamomile in the diet

\begin{tabular}{|c|c|c|c|c|c|c|c|c|}
\hline \multirow{2}{*}{ Treatment } & \multicolumn{2}{|c|}{ Head $(\%)$} & \multicolumn{2}{|c|}{ Back $(\%)$} & \multicolumn{2}{|c|}{ Tail $(\%)$} & \multicolumn{2}{|c|}{ Wing $(\%)$} \\
\hline & No & Yes & No & Yes & No & Yes & No & Yes \\
\hline \multicolumn{9}{|c|}{ Chamomile level (g/kg) } \\
\hline 0 & 68.28 & 31.72 & 96.55 & 3.45 & 98.62 & 1.38 & 95.17 & 4.83 \\
\hline 2.5 & 62.67 & 37.33 & 94.00 & 6.00 & 99.33 & 0.67 & 94.67 & 5.33 \\
\hline 5.0 & 65.33 & 34.67 & 94.67 & 5.33 & 98.67 & 1.33 & 96.00 & 4.00 \\
\hline \multicolumn{9}{|c|}{ Experimental day } \\
\hline 14 & 77.33 & 22.67 & 98.67 & 1.33 & 100.00 & 0.00 & 100.00 & 0.00 \\
\hline 28 & 68.92 & 31.08 & 91.89 & 8.11 & 100.00 & 0.00 & 97.30 & 2.70 \\
\hline 42 & 43.24 & 56.76 & 98.65 & 1.35 & 100.00 & 0.00 & 97.30 & 2.70 \\
\hline 56 & 70.27 & 29.73 & 97.30 & 2.70 & 95.95 & 4.05 & 89.19 & 10.81 \\
\hline 70 & 72.97 & 27.03 & 95.95 & 4.05 & 98.65 & 1.35 & 93.24 & 6.76 \\
\hline 84 & 59.46 & 40.54 & 87.84 & 12.16 & 98.65 & 1.35 & 94.59 & 5.41 \\
\hline \multicolumn{9}{|c|}{ Probability by Fischer's test } \\
\hline Chamomile & \multicolumn{2}{|c|}{$0.6168 \mathrm{NS}$} & \multicolumn{2}{|c|}{$0.6262 \mathrm{NS}$} & \multicolumn{2}{|c|}{$0.8726 \mathrm{NS}$} & \multicolumn{2}{|c|}{$0.8882 \mathrm{NS}$} \\
\hline Day & \multicolumn{2}{|c|}{$0.0001 * *$} & \multicolumn{2}{|c|}{$0.0157^{*}$} & \multicolumn{2}{|c|}{$0.1311 \mathrm{NS}$} & \multicolumn{2}{|c|}{$0.0276^{*}$} \\
\hline
\end{tabular}

NS - not significant.

* Significant at $5 \%$ probability.

** Significant at $1 \%$ probability. 
non-significant results, but they used low phytotherapeutic inclusions $(0-0.75 \mathrm{~g} / \mathrm{kg})$, which may have compromised the results.

Feeding behavior was influenced by days; this behavior affected the performance of the birds, since the feed intake was higher and feed conversion worse on the 84th day. According to the literature, as age increases, there is a decrease in performance due to higher feed intake, which leads to worse feed conversion. Abu Taleb et al. (2008) confirmed this effect in a study with Japanese quail fed herbal products for six weeks and observed a linear increase in the feed intake of these birds over the weeks.

The inclusion of chamomile did not influence the performance of the birds (relative production, feed intake, and feed conversion). Abd El-Galil et al. (2011) found an increase in feed intake of birds fed $0.75 \mathrm{~g}$ of chamomile $/ \mathrm{kg}$ and better feed conversion for the treatment with $0.50 \mathrm{~g}$ of chamomile/kg. Galib et al. (2011) reported an increase in feed intake and worse feed conversion with the inclusion of chamomile in the diet $(7.5 \mathrm{~g}$ of chamomile $/ \mathrm{kg}$ ). Abaza et al. (2003) reported that the addition of chamomile at a level of $2.5 \mathrm{~g} / \mathrm{kg}$ of broiler diet improved growth performance and feed conversion.

Differing chamomile compositions and the extract processing methods in the various studies may have influenced performance results. Chamomile extract may promote performance due to antimicrobial, antifungal, and anti-inflammatory properties (Abaza et al., 2003), or, depending upon the tannin concentration, it may impair feed intake and conversion (Dada et al., 2015). However, in the present study, there was no influence of chamomile on performance, as previously mentioned.

The NAP and AP behaviors and the BST were influenced by days. The highest intensity of NAP and AP behaviors and the highest BST were observed on day 14 .

It is known that adult quail, like chickens, increase interaction (aggressive or non-aggressive) after regrouping to reestablish the group hierarchy (Guzmán et al., 2013). This phenomenon generally occurs primarily in the first $24 \mathrm{~h}$ after regrouping (Odén et al., 2000) or in the first week (Guzmán et al., 2013). We believe quail may have a regrouping adaptation period greater than two weeks. In our other study, investigating the optimal amino acid supplementation for Japanese quail, a three-week period was necessary for adaption (unpublished). Furthermore, in other Japanese quail studies, the data collection has spanned long periods ranging from 84 to 140 days (Garcia et al., 2005, Ribeiro et al., 2013). Therefore, the greater expression of the AP and NAP behaviors at day 14 of the experiment is most likely the result of the adaptation period of these birds

The increased frequency of AP and NAP behaviors during the regrouping adaptation period is the probable cause for the highest BST on day 14. It is known that an increased frequency of movement results in heat production (Moura et al., 2011). According to Carvalho and Mara (2010), the thermal energy that movement produces elevates the body temperature of the bird and causes the blood flow to be deviated to peripheral regions of the body, thereby transporting the heat to the body surface for dissipation (Macari et al., 2002).

Tonic immobility is a defense behavior, preceded initially by the coping behavior and its response evoked by a stress situation (Marques et al., 2010). It is the final anti-predatory defense response of some species and is characterized by pretending to be dead to achieve an escape opportunity by inducing relaxation of the attention of the predator (Michelan et al., 2006). Chamomile treatment and days had effect on tonic immobility time and the values were similar to those found by Marques et al. (2010), considered normal for quail.

Lábaque et al. (2013), evaluating the thymol feed supplementation ( $2 \mathrm{~g}$ of thymol $/ \mathrm{kg}$ of feed), could therefore present beneficial consequences in terms of animal welfare and observed that the latency to struggle was shorter and the number of struggling bouts was higher in the thymol than in their control counterparts; they also suggested that thymol supplementation may be considered a management strategy to help reduce fear responses of birds when exposed to a stressful situation.

Wounds on the head, back, and wing had an effect on the experimental days, with a lower incidence of injuries occurring at 14 days. These results contradict the data observed for AP, NAP, and BST at 14 days, in which due to the reestablishment of the social hierarchy, there was a greater expression of pecking behavior and BST. Therefore, the frequency of wounds in quail correlates with the age of the birds and not with their regrouping. The probable cause for this is that, after establishing the social hierarchy in the group, competition for food and water begins, leading to conflicts and consequently, body injury.

\section{Conclusions}

Inclusion of chamomile extract reduces the aggressive pecking behavior and increases sitting frequency in laying quail. Although the birds sit longer, chamomile extract in the quail feed does not affect the performance of the birds and can be used during the laying period without negatively 
affecting production. The use of chamomile extract in the diet predisposes a reduction in the stress of Japanese quail, with a consequent gain in the welfare of cage-reared birds.

\section{References}

Abaza, I. M.; Asar, M. A.; El-Shaarrawi, G. E. and Hassan, M. F. 2003. Effect of using nigella seed, chamomile flowers, thyme flowers and harmala seed as feed additives on performance of broiler. Egypt Journal of Agriculture Research 81:735-749.

Abd El-Galil, K.; Mahmoud, H. A.; Hassan, A. M. and Morsy, A. S. 2011. Effect of addition chamomile flower meal to laying Japanese quail diets on productive and reproductive performance and some physiological functions. Egyptian Journal of Nutrition and Feeds 14:147- 158 .

Abu Taleb, A. M.; Hamodi, S. J. and El Afifi, S. H. F. 2008. Effect of using some medicinal plants (anise, chamomile and ginger) on productive and physiological performance of Japanese quail. Isotope \& Radiative Research 40:1061-1070.

Becker, M. and Dalponte, J. C. 1999. Rastros de mamíferos silvestres brasileiros. 2.ed. UnB/IBAMA, Brasília.

Carvalho, T. and Mara, L. S. 2010. Hidratação e nutrição no esporte. Revista Brasileira de Medicina do Esporte 16:33-40.

Dada, R.; Toghyani, M. and Tabeidian, S. A. 2015. The effect of chamomile flower (Matricaria chamomilla) extract and powder as growth promoter on growth performance and digestive organs of broiler chickens. Research Opinions in Animal and Veterinary Science 5:290-294.

Galib, A. M. A. and Khalel, E. K. 2011. The potency of chamomile flowers (Matricaria chamomilla) as feed supplements (growth promoters) on productive performance and hematological parameters constituents of broilers. International Journal of Poultry Science 10:726-729.

Garcia, E. A.; Mendes, A. A.; Pizzolante, C. C.; Saldanha, E. S. P. B.; Moreira, J.; Mori, C. and Pavan, A. C. 2005. Protein, methione+cystine and lysine levels for Japanese quails during the production phase. Brazilian Journal of Poultry Science 7:11-18.

Guzmán, D. A.; Pellegrini, S.; Kembro, J. M. and Marin, R. H. 2013. Social interaction of juvenile Japanese quail classified by their permanence in proximity to a high or low density of conspecifics. Poultry Science 92:2567-2575.

Heiblum, R.; Aizenstein, O.; Gvaryahu, G.; Voet, H.; Robinzon, B. and Snapir, B. 1998. Tonic immobility and open field responses in domestic fowl chicks during the first week of life. Applied Animal Behaviour Science 60:347-357.

Lábaque M. C.; Kembro J. M.; Luna A. and Marin R. H. 2013. Effects of thymol feed supplementation on female Japanese quail (Coturnix coturnix) behavioral fear response. Animal Feed Science and Technology 183:67-72.

Lourenço, T. C.; Mendonça, E. P.; Nalevaiko, P. C. I.; Melo, R. T.; Silva, P. L. and Rossi, D. A. V. 2013. Antimicrobial effect of turmeric (Curcuma longa) on chicken breast meat contamination. Brazilian Journal of Poultry Science 15:79-82.

Macari, M.; Furlan, R. L. and Gonzales, E. 2002. Fisiologia aviária aplicada a frangos de corte. 2.ed. Facta, Campinas.

Mahmmod, Z. A. 2013. The effect of chamomile plant (Matricaria chamomile) as feed additives on productive performance, carcass characteristics and immunity response of broilers. International Journal of Poultry Science 12:111-116.

Marques, R. H.; Gravena, R. A.; Silva, J. D. T.; Hada, F. H.; Silva, V. K.; Munari, D. P. and Moraes, V. M. B. 2010. Camomila como aditivo fitoterápico para codornas na fase de postura. Revista Brasileira de Saúde e Produção Animal 11:990-998.
McKay, D. L. and Blumberg, J. B. 2009. A review of the bioactivity and potential health benefits of chamomile tea (Matricaria recutita L.). Human Nutrition Research Center on Aging at Tufts University 20:519-530.

Michelan, C. M.; Michelan, L. D.; Paula, H. M. and Hoshino, K. 2006. Imobilidade tônica e imobilidade do nado forçado em cobaias. Revista de Etologia 8:89-95.

Moura, D. J.; Maia, A. P. A.; Verccelino, R. A.; Medeiros, B. B. L.; Sarubbi, J. and Griska, P. R. 2011. Uso da termografia infravermelha na análise da termorregulação de cavalo em treinamento. Engenharia Agrícola 31:23-32.

Nääs, I. A.; Romanini, C. E. B. R.; Neves, D. P.; Nascimento, G. R. and Vercellino, R. A. 2010. Broiler surface temperature distribution of 42-day-old chickens. Scientia Agrícola 67:497-502.

Nazareno, A. C.; Pandorfi, H.; Guiselini, C.; Vigoderis, R. B. and Pedrosa, E. M. R. 2011. Animal welfare in different housing systems of broiler production. Engenharia Agrícola 31:13-22.

Odén, K.; Vestergaard, K. S. and Algers, B. 2000. Space use and agonistic behaviour in relation to sex composition in large flocks of laying hens. Applied Animal Behaviour Science 67:307-320.

Pavan, A. C.; Garcia, E. A.; Móri, C.; Pizzolante, C. C. and Piccinin, A. 2005. Efeito da densidade na gaiola sobre o desempenho de poedeiras comerciais nas fases de cria, de recria e de produção. Revista Brasileira de Zootecnia 34:1320-1328.

Ribeiro, C.L.N.; Barreto, S.L.T.; Reis, R.S.; Muniz, J. C. L.; Donzele, J. L.; Gomes, P. C.; Vargas Júnior, J. G. and Albino, L. F. T. 2013. Digestible lysine levels in diets for laying Japanese quails. Revista Brasileira de Zootecnia 42:489-485.

Richards, S. A. 1971. The significance of changes in the temperature of the skin and body core of the chicken in the regulation of heat loss. Journal of Physiology 216:1-10.

Rocha, J. S. R.; Lara, L. J. C. and Baião, N. C. 2008. Produção e bemestar animal: aspectos éticos e técnicos da produção intensiva de aves. Ciências Veterinárias dos Trópicos 11:49-55.

Rostagno, H. S.; Albino, L. T. F.; Donzele, J. L.; Gomes, P. C.; Oliveira, R. F.; Lopes, D. C.; Ferreira, A. S.; Barreto, S. L. T. and Euclides, R. F. 2011. Composição de alimentos e exigências nutricionais de aves e suínos. Tabelas brasileiras para aves e suínos. 3.ed. Universidade Federal de Viçosa, Viçosa, MG.

Royer, A. F. B.; Garcia, R. G.; Borille, R.; Santana, M. R.; Nääs, I. A.; Caldara, F. R.; Almeida Paz, I. C. L.; Zeviani, W. M.; Alves, F. M. S.; Sgavioli, S. I. and Mariano, W. S. 2015. Welfare of broilers ingesting a pre-slaughter hydric diet of lemon grass. Brazilian Journal of Poultry Science 17:301-306.

Sarker, M. S. K.; Kim, G. M. and Yang, C. J. 2010. Effect of green tea and biotite on performance, meat quality and organ development in Ross broiler. Egypt Poultry Science 30:77-88.

Schmid, I. and Wechsler, B. 1997. Behaviour of Japanese quail (Coturnix japonica) kept in semi-natural aviaries. Applied Animal Behaviour Science 55:103-112.

Silva, J. H. V.; Jordão Filho, J.; Costa, F. G. P.; Lacerda, P. B.; Vargas, D. G. V. and Lima, M. R. 2012. Nutritional requirements of quails. Revista Brasileira de Saúde e Produção Animal 13:775-790.

Srivastava, J. K.; Shankar, E. and Gupta, S. 2010. Chamomile: A herbal medicine of the past with bright future. Molecular Medicine Reports 3:895-901.

Wang, L. A. and Goonewardene, Z. 2004. The use of MIXED models in the analysis of animal experiments with repeated measures data. Canadian Journal of Animal Science 84:1-11.

Yuan, C. S.; Mehendale, S.; Xiao, Y.; Aung, H. H.; Xie, J. T. and Ang-Lee, M. K. 2004. The gamma-aminobutyric acidergic effects of valerian and valerenic acid on rat brainstem neuronal activity. Anesthesia \& Analgesia Journal 98:353-358. 